\title{
Investigating the Use of Combined Hydrogen, Heat and Power System for Omar AL-Mukhtar University Campus
}

\author{
Moutaz Benali, Tarek Hamad, Ahmad Belkhair, Yousif Hamad \\ Department of Sustainable and Renewable Energy Engineering, Omar Al-Mukhtar University, El-Beida, Libya \\ Email: moutaz.benali@omu.edu.ly
}

How to cite this paper: Benali, M., Hamad, T., Belkhair, A. and Hamad, Y. (2019) Investigating the Use of Combined Hydrogen, Heat and Power System for Omar AL-Mukhtar University Campus. Advances in Biological Chemistry, 9, 31-44. https://doi.org/10.4236/abc.2019.91003

Received: January 9, 2019

Accepted: January 29, 2019

Published: February 1, 2019

Copyright ( 2019 by author(s) and Scientific Research Publishing Inc. This work is licensed under the Creative Commons Attribution International License (CC BY 4.0).

http://creativecommons.org/licenses/by/4.0/

\begin{abstract}
This paper investigates the use of a combined hydrogen, heat, and power (CHHP) system for Omar Al-Mukhtar University campus using local resources. Based on previous local resource assessment studies, the hydrogen team of Omar AL-Mukhtar University (OMU) selected the fuelcell energy DFC $4000^{\mathrm{TM}}$ unit. This study shows that the CHHP system can provide electricity to power the university campus, thermal energy for heating the anaerobic digester, and hydrogen for transportation, back-up power and other needs. Consequently, using the alternative fuels and renewable energy resources for OMU campus can lower fossil fuel consumption and, therefore, greenhouse gas emissions (GHG).
\end{abstract}

\section{Keywords}

Hydrogen, Feedstock, Anaerobic Digestion, Pressure Swing Adsorption, Renewable Energy

\section{Introduction}

OMU campus in El-Beida City is the fourth largest campus in Libya with $1.9 \mathrm{~km}^{2}$ and approximately 7000 students. The university is one of El-Beida's largest electric power consumers with a peak demand of $13.78 \mathrm{MWe}$ and electric energy consumption of $3 \times 10^{5} \mathrm{kWh} /$ day. Currently, electrical power of the university campus is purchased from General Electricity Company of Libya (GECOL) and distributed from the substation and switchgear located at the campus power plant. Biogas produced by anaerobic digestion of wastewater, organic waste, agricultural waste, animal waste, and industrial waste is a potential source of renewable energy. Treated biogas can be used to generate CHHP, using a molten 
carbonate fuelcell (MCFC) [1] [2] [3] [4]. An energy flow and resource availability study was performed to identify the type and source of feedstock required to continuously run the CHHP system to produce maximum capacity of electricity, heat recovery and hydrogen [5] [6]. The hydrogen generated is used to power different applications on the university campus, including personal transportation, backing power, portable power, and mobility/utility applications. Local available feed stocks near OMU campus that could be used for biogas production were identified [7] [8] [9]. This paper discusses the design and investigation of CHHP system at OMU campus by using local resources. The power generated by the CHHP system is used at various locations on the campus to reduce the total electric power purchased and minimizes air pollution to benefit overall community health. Therefore, the CHHP system has higher efficiency than other distributed generation plants of similar size [10].

\section{Experimental Procedure}

\subsection{Location}

Hydrogen team of OMU selected the location of the CHHP plant at OMU campus to be in the southwest side as shown in Figure 1. Due to the size of the system, the space needed should be sufficiently large as well. This location also satisfies safety and nuisance requirements due to the complication arising from storage of waste and hydrogen. The site also has the advantage of being near large enough road to allow for easy access by the campus's shuttle system. Furthermore, visibility of the CHHP plant in the campus will encourage promotion of clean waste-to-energy, hydrogen, and sustainability concepts of students and staff.

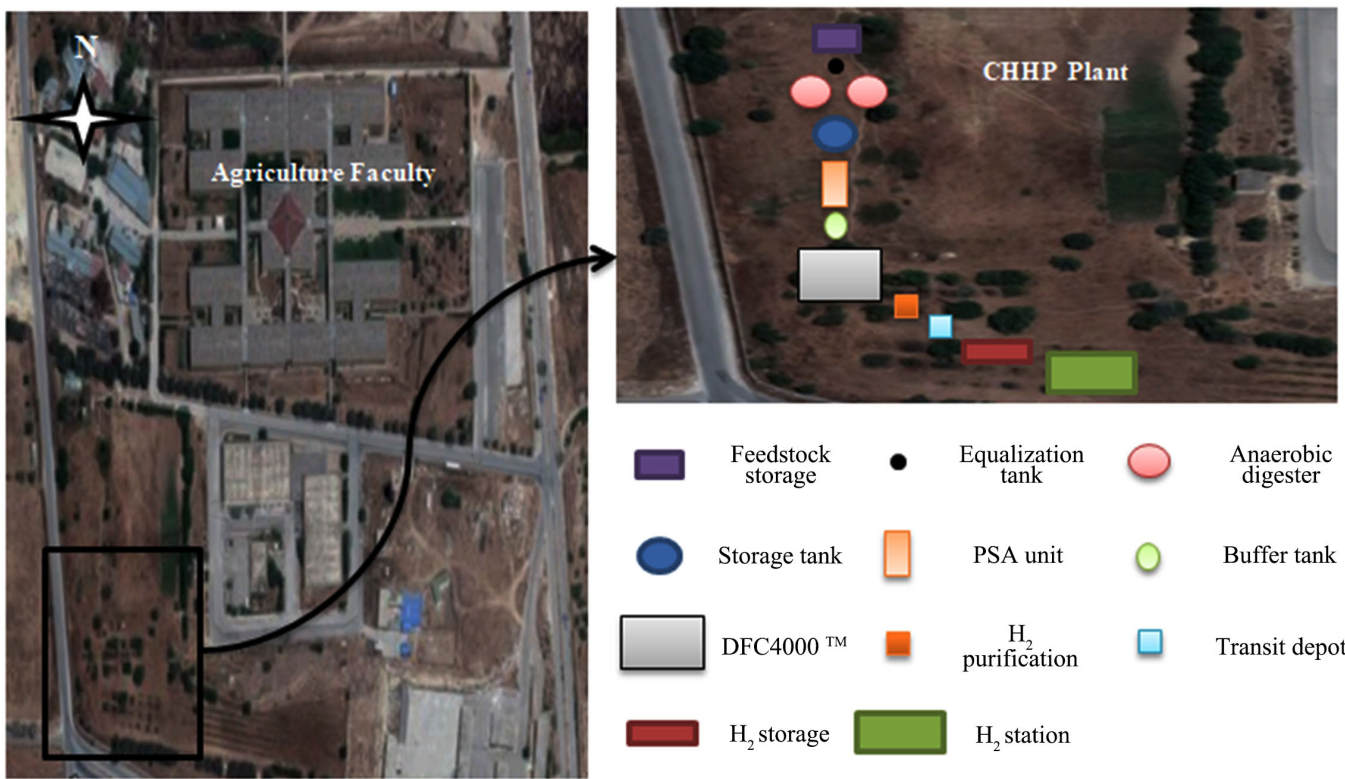

Figure 1. Location with anaerobic digester, CHHP plant, and hydrogen fueling station. Source google map. 


\subsection{CHHP System Technical Design}

This section describes the design of the major components and explains the various processes occurring during system operation. The design discussed in this paper has three major systems: 1) anaerobic digestion system, 2) CHHP system consisting of a DFC4000 ${ }^{\mathrm{TM}}$ fuelcell unit, and 3) Hydrogen recovery, cleaning, compression, storage, dispensing, and distribution system on university campus from CHHP system [3] [11]. These systems were designed based on the results from the feedstock assessment and the expected biogas production from local resources. It was found that the anticipated methane production after biogas treatment is $651.1 \mathrm{~m}^{3} / \mathrm{h}$ with a heat content of $159.66 \mathrm{MJ} / \mathrm{m}^{3}$. Consequently, a DFC4000 ${ }^{\mathrm{TM}}$ unit was selected for the CHHP system for which local resources can provide $100 \%$ of the fuel requirements. DFC $4000^{\mathrm{TM}}$ completely operates by biogas and does not need purchased natural gas from the local utility company.

The anaerobic digestion system and the CHHP system are sized based on the amount of locally available feedstock and the amount of methane gas generated respectively [12] [13]. The hydrogen recovery, purification, compression, storage, and distribution system are designed based on the hydrogen demand on the university campus and the $65 \%$ fuel utilization rate [14]. The following section describes the major components of the system.

\subsection{Feedstock Delivery System and Pretreatment Tank}

Feedstock is collected and transported to the storage facility. The storage facility consists of a $48.22 \mathrm{~m} \times 48.22 \mathrm{~m}\left(2325 \mathrm{~m}^{2}\right)$ steel building to protect the feedstock from the elements [15]. It houses a macerator to chop feedstock larger in diameter than $0.05 \mathrm{~m}$ to aid in the methane production rate in the digester. The design employs a 38 kWe Taskmaster 1600 shedder from Franklin Miller Incto that reduces the size of the feedstock [16] [17]. The processed feedstock will be stored in a cement storage bin in the storage facility.

\subsection{Anaerobic Digestion System}

Digesters and biogas production are shown in Figure 2 [18]. The feedstock from the cement storage bin is transported via a screw feeder to a hygiene station unit where it is heated to $70^{\circ} \mathrm{C}$ for one hour to remove all the pathogens [19] [20]. After heating, the feedstock is transported to a $113.5 \mathrm{~m}^{3}$ equalization tank where the biomass is mixed to form a homogenous mixture before being fed into the digester. The digester used in the design is a complete-mix anaerobic digester from Siemens Company and is a concrete tank with a diameter of $38.125 \mathrm{~m}$ and a tank side water depth of $16 \mathrm{~m}$. The tank wall height below grade is $18.25 \mathrm{~m}$ and has a floor slope of 1:6. The outer wall is insulated and the inner wall of the tank is lined with stainless steel hot water pipes to maintain an optimum temperature of $40^{\circ} \mathrm{C}$.

The design uses a highly efficient Jet Mix $^{\text {tix }}$ Vortex Mixing System by Siemens, to mix the biomass inside the digester. The system suspends organic and inor- 
ganic solids with intermittent mixing, making possible power savings of up to $50 \%$ or more. The system maintains efficiency regardless of tank level and minimizes dead spots due to its innovative mixing pattern and also has the capability to mix multiple tanks using one central pumping facility. This system will eliminate the use of multiple pumps and will reduce the capital cost of the digester system. The proposed anaerobic digester is sized such that it has retention time of 21 days. The specification and details of the digester are shown in Table 1 [21] [22].

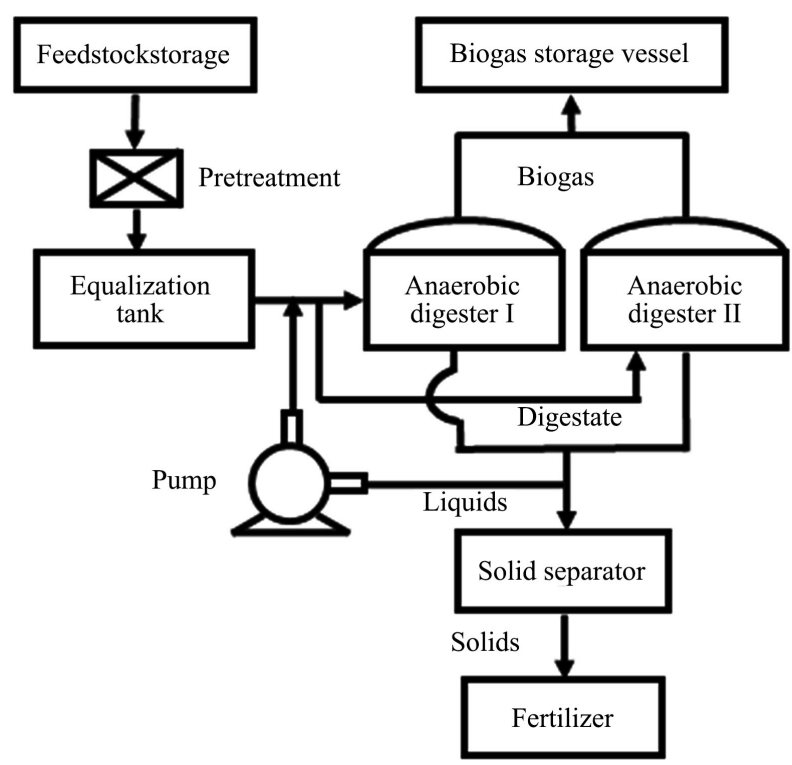

Figure 2. Flow diagram for digester and biogas production.

Table 1. Digester data.

\begin{tabular}{cc}
\hline Tank side water depth & $16 \mathrm{~m}$ \\
\hline Tank wall height (below grade) & $18.25 \mathrm{~m}$ \\
Tank diameter & $38.125 \mathrm{~m}$ \\
Cone per tank & $1115 \mathrm{~m}^{3}$ \\
Tank wall thickness & $0.30 \mathrm{~m}$ \\
Floor slope & $1: 6$ \\
Quantity of solids to digester & $36 \times 10^{3} \mathrm{~kg} /$ day \\
Retention time & $21 \mathrm{days}$ \\
Volatile solids concentration & $80 \%$ \\
Anticipated solids reduction & $50 \%$ \\
Anticipated gas yield & $0.93 \mathrm{~m}^{3} / \mathrm{kgVS}^{\text {destroyed }}$ \\
Anticipated biogas production & $550 \mathrm{~m}^{3} / \mathrm{h}$ \\
Volatile solids &
\end{tabular}


Inside the anaerobic digester, microorganisms act on the organic feedstock to produce biogas; digest ate, and water [10]. The anticipated biogas production from the digester is $1100 \mathrm{~m}^{3} / \mathrm{h}$ or $660 \mathrm{~m}^{3} / \mathrm{h}$ of natural gas equivalent (assuming biogas concentration is $60 \%$ methane and $40 \%$ carbon dioxide) [1] [23].

\subsection{Gas Treatment System and Fuel Storage}

Two main adsorption technologies are being considered: pressure swing adsorption (PSA) and temperature swing adsorption (TSA). The mean difference between the PSA and TSA methods refers to the strategy for regenerating the adsorbent after the adsorption step and the time duration of an individual adsorption circle and adsorption circle in varied temperature technology generally takes several times longer than in varied-pressure technology. On other hand, in PSA applications, the pressure of the bed is reduced, whereas in TSA, the temperature is raised while pressure is maintained approximately constant. In this project, the step time for desorption is of the same order of magnitude as that of the adsorption (sometimes even smaller). Consequently, this process enjoys shorter cycle time and better efficiency also by using Zeolites 13X compared to TSA, and accordingly, is chosen. In addition, the most of studies dealing with $\mathrm{CO}_{2}$ capture use Zeolites $13 \mathrm{X}$ as adsorbent in PSA or TSA technologies because Zeolite $13 \mathrm{X}$ has high selectivity to $\mathrm{CO}_{2}$.

Biogas from the anaerobic digestion is stored in a buffer tank which supplies biogas to the gas treatment system. The treatment system uses PSA technology to separate methane present in the biogas [24] [25]. The design has a total of eight absorbers to ensure a continuous stream of high quality methane. While carbon dioxide $\left(\mathrm{CO}_{2}\right)$, hydrogen sulfide $\left(\mathrm{H}_{2} \mathrm{~S}\right)$ and other impurities in one set of tanks are desorbing, biogas will be fed to the second set of tanks for adsorption. The product from this gas treatment system is pipe line quality natural gas which is fed into the fuelcell [26] [27]. Even though the DFC fuelcell units can handle $60 \%$ methane and $40 \%$ carbon dioxide without affecting its efficiency, the design included the PSA unit for the following reasons [1]:

- The DFC ${ }^{\circ}$ units cannot accept $\mathrm{H}_{2} \mathrm{~S}$, water $\left(\mathrm{H}_{2} \mathrm{O}\right)$, and other impurities in its input fuel. Therefore, biogas treatment is necessary before feeding it into the fuelcell under all conditions [1] [28].

- Inlet fuel pressure to the fuelcell should be between $2-2.4$ bars. If the fuel contains $40 \%$ carbon dioxide, it will impact the sizing and the equipment downstream the fuelcell of the design will require a higher capacity heat exchanger, water-gas shift reactor, and hydrogen purification or separation system. The DFC $4000^{\mathrm{TM}}$ requires $651.1 \mathrm{~m}^{3} / \mathrm{h}$ of natural gas at $34.65 \mathrm{MJ} / \mathrm{m}^{3}$. If biogas (60\% methane and $40 \%$ carbon dioxide) is utilized, the fuelcell system will require $477 \mathrm{~m}^{3} / \mathrm{h}$ of biogas as fuel to operate. This will increase the size of the equipment downstream the fuelcell by $55 \%$ and will increase its capital cost which is not desirable [1] [29].

- The product gas from the PSA unit is expected to have an average heat con- 
tent of $34.65 \mathrm{MJ} / \mathrm{m}^{3}$ which is roughly equal to the average heat content of natural gas consumed in OMU $\left(34.65 \mathrm{MJ} / \mathrm{m}^{3}\right)$. Hence, the fuelcell unit will receive a consistent fuel throughout its operation. The process and flow during the biogas treatment is illustrated in Figure 3.

\section{DFC4000 ${ }^{\mathrm{TM}}$ Fuel Cell Power Plant}

The two anaerobic digesters system will be able to supply $100 \%$ of fuel for the $\mathrm{DFC} 4000^{\mathrm{TM}}$ unit from locally available feedstock. Figure 4 shows the reactions taking place inside the fuelcell [1] [13].

\subsection{Anode Outlet Gas (AOG) Calculations}

The AOG calculations are remade based on the AOG composition calculation document provided by fuelcell energy [23] [30]. It is assumed that all methane entering the $\mathrm{DFC}^{\circ}$ unit is internally reformed at $600^{\circ} \mathrm{C}$ and converted to hydrogen

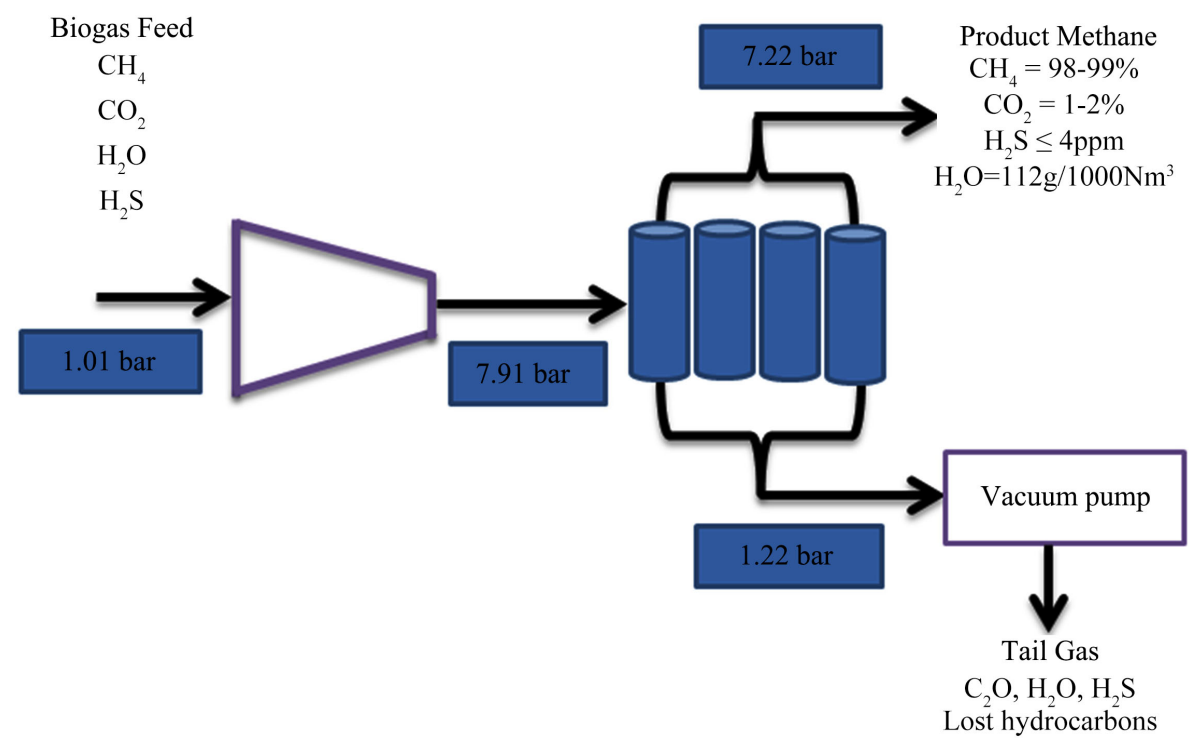

Figure 3. The process and flow during the biogas treatment.

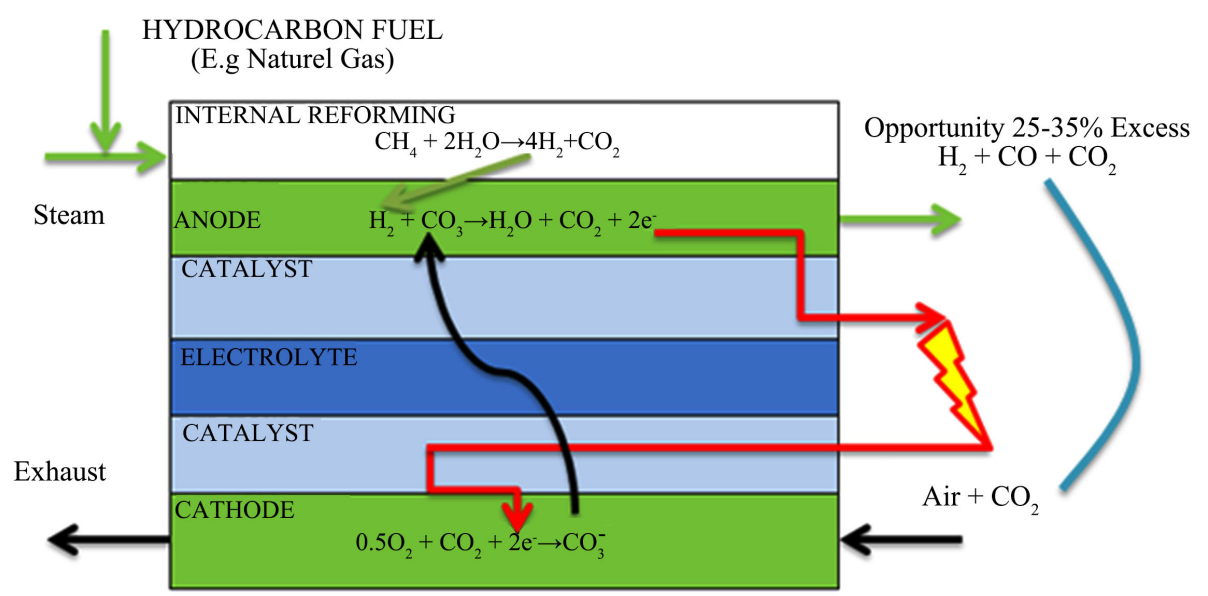

Figure 4. Internal reforming $\mathrm{DFC}^{\circledast}$ technology. 
and that only $65 \%$ (the fuel utilization rate) of the $\mathrm{H}_{2}$ produced is reacted at the anode to produce electricity. In order to reflect the AOG composition, it is assumed that one third of the $35 \%$ hydrogen produced is back-shifted to produce $\mathrm{H}_{2} \mathrm{O}$ and $\mathrm{CO}$. Based on these assumptions and the processes taking place inside the fuelcell, the following Equations (1)-(5) for every one mole of methane $\left(\mathrm{CH}_{4}\right)$ entering the anode side are obtained.

Internal reforming:

$$
\mathrm{CH}_{4}+2 \mathrm{H}_{2} \mathrm{O} \rightarrow 4 \mathrm{H}_{2}+\mathrm{CO}_{2}
$$

Assuming one mole of $\mathrm{CH}_{4}$ is fed to the $\mathrm{DFC}^{*}$ system; only $65 \%$ of the hydrogen (i.e. 2.6 moles) reacts at the anode and will result in the following equation.

Corresponding reaction at anode:

$$
2.6 \mathrm{H}_{2}+2.6 \mathrm{CO}_{3}^{--} \rightarrow 2.6 \mathrm{H}_{2} \mathrm{O}+2.6 \mathrm{CO}_{2}+2 \mathrm{e}^{-}
$$

The remaining $35 \%$ of the $\mathrm{H}_{2}$ (1.4 moles) and the entire $\mathrm{CO}_{2}$ (1 mole) from Equation (1) goes directly to the AOG. Combining the products from (2) and 1.4 moles of $\mathrm{H}_{2}$ and 1 mole of $\mathrm{CO}_{2}$ from (1) results in the following AOG composition.

$$
1.4 \mathrm{H}_{2}+2.6 \mathrm{H}_{2} \mathrm{O}+3.6 \mathrm{CO}_{2}
$$

But in reality, another internal reaction takes place in the $\mathrm{DFC}^{\circ}$ fuel cell. One third of the $\mathrm{H}_{2}$ in Equation (3) (i.e. 0.47 moles) needs to back-shifted to $\mathrm{H}_{2} \mathrm{O}$ and $\mathrm{CO}$ resulting in Equation (4).

$$
0.47 \mathrm{H}_{2}+0.47 \mathrm{CO}_{2} \rightarrow 0.47 \mathrm{H}_{2} \mathrm{O}+0.47 \mathrm{CO}
$$

Combining Equations (3) and (4) yields the following products:

$$
0.93 \mathrm{H}_{2}+3.07 \mathrm{H}_{2} \mathrm{O}+0.47 \mathrm{CO}+3.13 \mathrm{CO}_{2}
$$

The inlet fuel requirement of the $\mathrm{DFC} 4000^{\mathrm{TM}}$ unit based on $156 \mathrm{MJ} / \mathrm{m}^{3}$ input fuel is calculated and found to be $651.1 \mathrm{~m}^{3} / \mathrm{h}$. Assuming that the input fuel consists of $98 \% \mathrm{CH}_{4}$ and $2 \% \mathrm{CO}_{2}, 651.1 \mathrm{~m}^{3} / \mathrm{h}$ of fuel consists of 451 moles of $\mathrm{CH}_{4}$ and 9 moles of $\mathrm{CO}_{2}$. The actual AOG flow rate corresponding to 451 moles of methane per minute is calculated using Equation (5).

\subsection{Hydrogen Recovery and Purification System}

In order to succeed a CHHP system, hydrogen from the AOG must be recovered, cleaned and distributed from the $\mathrm{DFC}^{\circ}$ fuelcell system. This section explains the hydrogen recovery and water-gas shift reaction for additional hydrogen production, removal and recycling of water, purification of hydrogen gas, and $\mathrm{CO}_{2}$ transfer to the cathode side of the fuelcell [31]. The details of the hydrogen recovery and purification process are shown in Figure 5.

The AOG outlet pressure is 1.08 bar and outlet temperature to be $600^{\circ} \mathrm{C}$. The AOG is first cooled and pressurized to undergo water-gas shift reaction.

Water-gas shift reaction:

$$
\mathrm{H}_{2} \mathrm{O}+\mathrm{CO} \rightarrow \mathrm{H}_{2}+\mathrm{CO}_{2}
$$




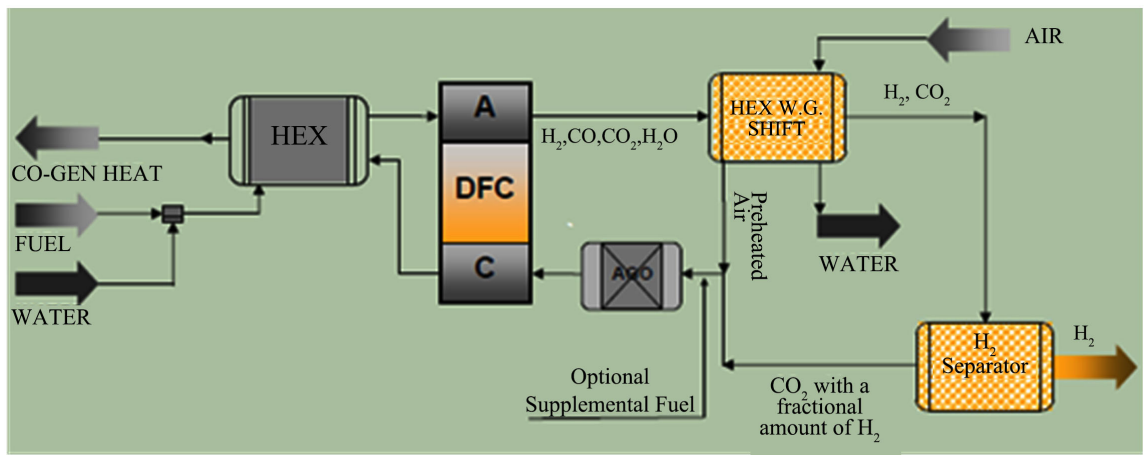

Figure 5. Hydrogen recovery and purification.

The entire $\mathrm{CO}$ present in the AOG reacts with $\mathrm{H}_{2} \mathrm{O}$ to produce an additional $242 \mathrm{~kg}$ of $\mathrm{H}_{2}$ and of $4 \times 10^{3} \mathrm{~kg}$ of $\mathrm{CO}_{2}$ per day. The water vapor is condensed and recycled to the anode side of the fuelcell for the internal reforming of methane. The amount of water produced during condensation is greater than the fuelcell requirement with the excess water is sent into the sewer. The $\mathrm{CO}_{2}$ and $\mathrm{H}_{2}$ coming out of the water-gas shift reactor is cooled and separated using a PSA unit. The hydrogen coming out of the PSA unit is compressed and used for different applications on the university campus. Outside air is preheated using the heat exchanger and is mixed with the $\mathrm{CO}_{2}$ coming out the PSA unit in Anode Gas Oxidizer (AGO). The mixture is then transferred to the cathode to complete the cathode reaction as shown in Equation (7).

Reaction at cathode:

$$
\mathrm{CO}_{2}+0.5 \mathrm{O}_{2}+2 \mathrm{e}^{-} \rightarrow \mathrm{CO}_{3}
$$

The flow rates of gases at different stages were estimated and tabulated in $\mathrm{Ta}$ ble 2. Theses flow rates are necessary to calculate the amount of hydrogen generated, amount of outside air needed, and amount of exhaust gas. The following assumptions were made during the calculations: 1) $\mathrm{H}_{2}$ recovery rate from PSA unit is $90 \%$; 2) air consist of $79 \% \mathrm{~N}_{2}$ and $\left.21 \% \mathrm{O}_{2} ; 3\right) \mathrm{N}_{2}$ is inert and does not take part in the cathode reactions; 4) amount of outside air was calculated based on the amount of $\mathrm{CO}_{2}$ present on the PSA tail gas; 5) only $70 \%$ of $\mathrm{CO}_{2}$ undergoes reaction to maintain the $\mathrm{CO}_{3}{ }^{-}$equilibrium inside the fuelcell. Based on the hydrogen flow rate from the PSA product outlet, the amount of hydrogen generated per day is approximately $1480 \mathrm{~kg}$.

\subsection{Hydrogen Compression, Storage, Dispensing/Distribution System}

The system will be incorporated into the existing hydrogen infrastructure on the university campus. The existing hydrogen station was designed such that it could handle higher volume of hydrogen in the future. The product hydrogen from the PSA unit will be transferred into the buffer tank located in the adjacent hydrogen station via pipeline. The buffer tank feds two compressors: 1) the existing Hydro-Pac C06-10-70/140LX compressor (415 bars) and 2) the PDC ma- 
chines (PDC-13-1000-3000) compressor (250 bars). The compressed hydrogen from the Hydro-Pac compressor will be stored in existing storage tanks. Hydrogen from the PDC machine compressor will be used to fill a hydrogen tube trailer and K-cylinder manifold.

\section{Results and Discussion}

\subsection{Application Energy End-Uses on the University Campus from CHHP System}

This section explains how to use the output from the DFC4000 ${ }^{\mathrm{TM}}$ fuelcell (Heat, Hydrogen, and Electricity on the campus). Fuelcells operating on methane from biogas offer a pathway to renewable electricity generation Tri-generation of electricity, heat, and hydrogen offers an alternative route to solving the $\mathrm{H}_{2}$ infrastructure problem facing fuelcell vehicle deployment. Consequently, it will be promoting biogas fuelcells in the future under its market transformation programs. Finally, this part gives details for calculation electric, heat recovery, and hydrogen output from the CHHP system.

\subsection{Electricity Use}

The electric power output of the DFC4000 ${ }^{\mathrm{TM}}$ unit operating in the simple cycle CHP mode is 3.7 MWe. This corresponds to the net power after providing the parasitic loads for its Mechanical Balance of the Plant (M-BOP) and energy loss in the Electrical Balance of the Plant (E-BOP). However, there are additional components that require electric power for the $\mathrm{DFC} 4000^{\mathrm{TM}}$ unit operating in CHHP mode. These components, including the heat exchanger for AOG cooling, the water-gas shift reactor, and the PSA unit for hydrogen purification and operate collectively with the fuelcell unit to form the CHHP system. Based on the power requirements of these components, the net power output from the CHHP system was estimated to be $3.2 \mathrm{MWe}$. The total electric power requirement of different equipment used in the design is estimated to be approximately $474 \mathrm{kWe}$ and is tabulated in Table 3.

Auxiliary loads include site lighting, safety devices, hydrogen dispenser, and electric loads at central control station. The total net energy production from the CHHP system is $76.8 \times 10^{3} \mathrm{kWh}$ per day and the energy demand for on-site use is $8000 \mathrm{kWh}$ per day. Hence, the CHHP system will be able to provide $68.8 \times 10^{3}$ $\mathrm{kWh}$ per day to the university campus. This corresponds to $23 \%$ of the whole campus electricity requirement.

\subsection{The Heat Recovery System Use}

The DFC $4000^{\mathrm{TM}}$ unit has $4 \mathrm{GJ} / \mathrm{h}$ at $49^{\circ} \mathrm{C}$ available for heat recovery while operating in CHP mode. However, the recoverable heat from a DFC4000 ${ }^{\mathrm{TM}}$ unit operating in CHHP mode is considerably lower than compared to the operating in CHP mode. This is due to the cooling of anode outlet gas, removal of water vapor, hydrogen recovery, and lower flow rate of the exhaust gases. The thermal energy available for heat recovery was calculated based on the cathode exhaust 
gas composition and Equation (8) is shown in Table 4. The temperature difference of the input and output temperature of the heat recovery system is approximately $322^{\circ} \mathrm{C}$.

$$
Q=m \times C_{P}(\Delta T)
$$

where $m, C_{P}$ and $\Delta T$ are the mass flow rate of the gas $(\mathrm{kg} / \mathrm{h})$, the specific heat of the gas $(\mathrm{kJ} / \mathrm{kg} \cdot \mathrm{K})$ and the change in temperature of the gas $(\mathrm{K})$ respectively.

The low thermal energy from the DFC $4000^{\mathrm{TM}}$ unit can be attributed to the low flow rate of the exhaust gases when compared to the DFC $4000^{\mathrm{TM}}$ in CHP cycle. Two components in the system that require heat energy are 1) hygienization unit and 2) anaerobic digester. Hygienization of feedstock prevents pathogens from entering the digester and maintaining optimum temperature inside the anaerobic digester ensures maximum biogas production. The mass of the feedstock and digester sludge that need to be heated are $36 \times 10^{3} \mathrm{~kg} /$ day and $12 \times 10^{6} \mathrm{~kg} /$ day, respectively. The temperature of feedstock was assumed to be $20^{\circ} \mathrm{C}$. The digester is heated to $40^{\circ} \mathrm{C}$ during its initial fill and is assumed to lose $1^{\circ} \mathrm{C}$ on average every hour due to environmental losses. Table 5 shows that the total load for these two systems is greater than the recoverable heat. Therefore, additional thermal load requirement will be met using an external natural gas heater.

Table 2. Flow of gases at different sections of the system.

\begin{tabular}{ccccccc}
\hline Gas & $\begin{array}{c}\text { HEX W.G. } \\
\text { shift inlet } \\
(\mathrm{mol} / \mathrm{min})\end{array}$ & $\begin{array}{c}\text { HEX W.G. } \\
\text { shift outlet } \\
(\mathrm{mol} / \mathrm{min})\end{array}$ & $\begin{array}{c}\text { PSA product } \\
\text { outlet } \\
(\mathrm{mol} / \mathrm{min})\end{array}$ & $\begin{array}{c}\text { PSA tail gas } \\
(\mathrm{mol} / \mathrm{min})\end{array}$ & $\begin{array}{c}\text { AGO inlet } \\
(\mathrm{mol} / \mathrm{min})\end{array}$ & $\begin{array}{c}\text { cathode exhaust } \\
(\mathrm{mol} / \mathrm{min})\end{array}$ \\
\hline $\mathrm{H}_{2}$ & 356.5 & 536.6 & 483 & 53.6 & 53.6 & 53.6 \\
$\mathrm{CO}_{2}$ & 1200.2 & 1380.3 & - & 1380.3 & 1380.3 & 414.1 \\
$\mathrm{H}_{2} \mathrm{O}$ & 1177.2 & 997.2 & - & - & - & - \\
$\mathrm{CO}$ & 180.2 & - & - & - & - & - \\
$\mathrm{O}_{2}$ & - & - & - & - & 690.15 & 207.05 \\
$\mathrm{~N}_{2}$ & - & - & - & - & 2597 & 2597 \\
\hline
\end{tabular}

Table 3. Power demand and energy consumption.

\begin{tabular}{cccc}
\hline Equipment & $\begin{array}{c}\text { Max. power } \\
\text { rating }(\mathrm{kWe})\end{array}$ & $\begin{array}{c}\text { Daily operation } \\
\text { Time }(\mathrm{h})\end{array}$ & $\begin{array}{c}\text { Daily energy } \\
\text { consumption }(\mathrm{kWh})\end{array}$ \\
\hline Feedstock storage facility & 7 & 12 & 84 \\
Macerator & 38 & 4 & 152 \\
Screw feeder & 7 & 4 & 28 \\
Pump & 100 & 4 & 400 \\
Hygienization unit & 9 & 4 & 36 \\
Anaerobic digester & 8 & 24 & 192 \\
Storage tank & 7 & 24 & 168 \\
Biogas PSA unit & 95 & 24 & $2.28 \times 10^{3}$ \\
Hydrogen compressor Comp1 & 12.5 & 24 & 300 \\
Hydrogen compressor Comp2 & 165 & 24 & $3.96 \times 10^{3}$ \\
Auxiliary loads & 25 & 16 & 400 \\
Total & 473.5 & 164 & 8,000
\end{tabular}


Table 4. Thermal energy available for heat recovery from the DFC4000 ${ }^{\mathrm{TM}}$ CHHP system.

\begin{tabular}{cccccc}
\hline Gas & $\begin{array}{c}\text { Cathode exhaust } \\
(\mathrm{kmol} / \mathrm{min})\end{array}$ & $\begin{array}{c}\text { Mass flow rate } \\
(\mathrm{kg} / \mathrm{h})\end{array}$ & $\begin{array}{c}\mathrm{Cp} \\
(\mathrm{kJ} / \mathrm{kg} \cdot \mathrm{K})\end{array}$ & $\begin{array}{c}\Delta \mathrm{T} \\
(\mathrm{K})\end{array}$ & $\begin{array}{c}\text { Q flow rate } \\
(\mathrm{MJ} / \mathrm{h})\end{array}$ \\
\hline $\mathrm{H}_{2}$ & 0.054 & 6.41 & 14.32 & 322 & 29.6 \\
$\mathrm{CO}_{2}$ & 0.414 & 451.95 & 0.84 & 322 & 122.2 \\
$\mathrm{O}_{2}$ & 0.207 & 347.56 & 0.92 & 322 & 103 \\
$\mathrm{~N}_{2}$ & 2.597 & 4985.1 & 1.04 & 322 & 1669.4 \\
Total & & 5791.02 & & & 1924.2 \\
\hline
\end{tabular}

Table 5. Thermal load of the system.

\begin{tabular}{ccccc}
\hline Thermal load & Mass flow rate $(\mathrm{kg} / \mathrm{h})$ & $\begin{array}{c}\mathrm{Cp} \\
(\mathrm{kJ} / \mathrm{kg} \cdot \mathrm{K})\end{array}$ & $\begin{array}{c}\Delta \mathrm{T} \\
(\mathrm{K})\end{array}$ & $\begin{array}{c}\mathrm{Q} \text { flow rate } \\
(\mathrm{MJ} / \mathrm{h})\end{array}$ \\
\hline Hygienization unit & 1500 & 2.3 & 50 & 172.5 \\
Anaerobic digester & 500,000 & 4.2 & 1 & 2100 \\
Total & & & & 2272.5 \\
\hline
\end{tabular}

\section{Conclusion}

In this paper the design of a CHHP system for OMU campus using local resources is studied. The study shows that the CHHP system can provide electricity to power the university campus, thermal energy for heating the anaerobic digester, and hydrogen for transportation, back-up power and other needs. The CHHP system will be able to provide approximately $68,800 \mathrm{kWh}$ and 1480 $\mathrm{kg} /$ day of hydrogen to the university campus. Ultimately, the CHHP system will reduce energy consumption, fossil fuel usage, and GHG. It will be able to provide approximately $23 \%$ of the university campus's electricity need.

\section{Acknowledgements}

The authors wish to acknowledge the Hydrogen Education Foundation for their support of the annual Hydrogen Student Design Contest which challenges university students to design hydrogen energy applications for real-world use.

\section{Conflicts of Interest}

The authors declare no conflicts of interest regarding the publication of this paper.

\section{References}

[1] Hamad, T.A., Agll, A.A., Hamad, Y.M., Bapat, S., Thomas, M., Martin, K.B., et al. (2014) Study of a Molten Carbonate Fuel Cell Combined Heat, Hydrogen and Power System. Energy, 75, 579-588. https://doi.org/10.1016/j.energy.2014.08.020

[2] Hamad, T.A., Agll, A.A., Hamad, Y.M., Bapat, S., Thomas, M., Martin, K.B., et al. (2013) Study of a Molten Carbonate Fuel Cell Combined Heat, Hydrogen and Power System: End-Use Application. Case Studies in Thermal Engineering, 1, 45-50. https://doi.org/10.1016/j.csite.2013.09.001

[3] Hamad, T.A., Agll, A.A., Hamad, Y.M., Bapat, S., Thomas, M., Martin, K.B., et al. 
(2014) Hydrogen Recovery, Cleaning, Compression, Storage, Dispensing, Distribution System and End-Uses on the University Campus from Combined Heat, Hydrogen and Power System. International Journal Hydrogen Energy, 39, 647-653. https://doi.org/10.1016/j.ijhydene.2013.10.111

[4] Hamad, T.A., Agll, A.A., Hamad, Y.M., Bapat, S., Thomas, M., Martin, K.B., et al. (2014) Hydrogen Production and End-Uses from Combined Heat, Hydrogen and Power System by Using Local Resources. Renewable Energy, 71, 381-386. https://doi.org/10.1016/j.renene.2014.05.054

[5] Vera, D., Jurado, F., de Mena, B. and Schories, G. (2011) Comparison between Externally Fired Gas Turbine and Gasifier-Gas Turbine System for the Olive Oil Industry. Energy, 36, 6720-6730. https://doi.org/10.1016/j.energy.2011.10.036

[6] Hamad, T.A., Agll, A.A., Hamad, Y.M., Bapat, S., Thomas, M., Martin, K.B., et al. (2014) Study of Combined Heat, Hydrogen and Power System Based on a Molten Carbonate Fuel Cell Fed by Biogas Produced by Anaerobic Digestion. Energy Conversion and Management, 81, 184-191.

https://doi.org/10.1016/j.enconman.2014.02.036

[7] Hamad, Y.M., Hamad, T.A., Agll, A.A., Bapat, S., Thomas, M., Martin, K.B., et al. (2013) Molten Carbonate Fuel Cell Combined Heat, Hydrogen and Power System: Feedstock Analysis. Energy Science and Technology, 6, 1-5.

[8] Agll, A.A., Hamada, Y.M., Hamada, T.A., Thomasb, M., Bapata, S., Martinc, K.B., et al. (2013) Study of a Molten Carbonate Fuel Cell Combined Heat, Hydrogen and Power System: Energy Analysis. Applied Thermal Engineering, 59, 634-638. https://doi.org/10.1016/j.applthermaleng.2013.06.030

[9] Demirbas, A. (2008) Importance of Biomass Energy Sources for Turkey. Energy Policy, 36, 834-842. https://doi.org/10.1016/j.enpol.2007.11.005

[10] Hamad, T.A., Agll, A.A., Hamad, Y.M., Sheffield, J.W. (2014) Solid Waste as Renewable Source of Energy: Current and Future Possibility in Libya. Case Studies in Thermal Engineering, 4, 144-152. https://doi.org/10.1016/j.csite.2014.09.004

[11] Odlare, M., Arthurson, V., Pell, M., Svensson, K., Nehrenheim, E. and Abubaker, J. (2011) Land Application of Organic Waste-Effects on the Soil Ecosystem. Applied Energy, 88, 2210-2218. https://doi.org/10.1016/j.apenergy.2010.12.043

[12] Yu, M., Muy, S., Quader, F., Bonifacio, A., Varghese, R., Clerigo, E., et al. (2013) Combined Hydrogen, Heat and Power (CHHP) Pilot Plant Design. International Journal of Hydrogen Energy, 38, 4881-4888. https://doi.org/10.1016/j.ijhydene.2013.02.006

[13] Pronto, J.L. and Gooch, C.A. (2010) Greenhouse Gas Emission Reductions for Seven On-Farm Dairy Manure-Based Anaerobic Digestion Systems-Final Results. $A S A B E, 7,735-742$. http://elibrary.asabe.org/abstract.asp?aid=32617

[14] Cantrell, K.B., Ducey, T. and Ro, K.S. (2008) Livestock Waste-to-Bioenergy Generation Opportunities. Bioresource Technology, 99, 7941-7953.

https://doi.org/10.1016/j.biortech.2008.02.061

[15] Ghaderi, A., Parsa Moghaddam, M. and Sheikh-El-Eslami, M.K. (2014) Energy Efficiency Resource Modeling in Generation Expansion Planning. Energy, 68, 529-537. https://doi.org/10.1016/j.energy.2014.02.028

[16] Larrasoana, J.C., Roberts, A.P., Rohling, E.J., Winklhofer, M. and Wehausen, R. (2003) Three Million Years of Monsoon Variability over the Northern Sahara. Climate Dynamics, 21, 689-698. https://doi.org/10.1007/s00382-003-0355-z 
[17] El Jrushi, G.S. and Veziro Tglu, T. (1990) Solar-Hydrogen Energy System for Libya. International Journal of Hydrogen Energy, 15, 885-894. https://doi.org/10.1016/0360-3199(90)90077-C

[18] Bouckaert, S., Assoumou, E., Selosse, S. and Maïzi, N. (2014) A Prospective Analysis of Waste Heat Management at Power Plants and Water Conservation Issues Using a Global TIMES Model. Energy, 68, 80-91. https://doi.org/10.1016/j.energy.2014.02.008

[19] Hawas, M.M. and Muneer, T. (1980) Monthly Average Daily Insolation on Tilted Collectors in Libya. Energy Conversion and Management, 20, 213-218. https://doi.org/10.1016/0196-8904(80)90037-0

[20] Sawalem, M., Selic, E. and Herbell, J. (2009) Hospital Waste Management in Libya: A Case Study. Waste Management, 29, 1370-1375. https://doi.org/10.1016/j.wasman.2008.08.028

[21] De Prá, M.C., Anschau, A., Busso, C., Gabiatti, N. and Bortoli, M. (2019) Effect of Short-Chain Fatty Acid Production on Biogas Generation. Improving Biogas Production, 9, 199-216. https://doi.org/10.1007/978-3-030-10516-7_9

[22] Peces, M., Astals, S., Clarke, W.P. and Jensen, P.D. (2016) Semi-Aerobic Fermentation as a Novel Pre-Treatment to Obtain VFA and Increase Methane Yield from Primary Sludge. Bioresource Technology, 200, 631-638. https://doi.org/10.1016/j.biortech.2015.10.085

[23] Huang, W. and Zhang, Y. (2011) Energy Efficiency Analysis: Biomass-to-Wheel Efficiency Related with Biofuels Production, Fuel Distribution, and Powertrain Systems. PLoS ONE, 6, Article ID: 0022113. https://doi.org/10.1371/journal.pone.0022113

[24] Rivarolo, M., Bogarin, J., Magistri, L. and Massardo, A. (2012) Time-Dependent Optimization of a Large Size Hydrogen Generation Plant Using "Spilled" Water at Itaipu $14 \mathrm{GW}$ Hydraulic Plant. International Journal of Hydrogen Energy, 37, 4434-5443. https://doi.org/10.1016/j.ijhydene.2011.09.015

[25] Tápparo, D.C., do Amaral, A.C., Steinmetz, R.L.R. and Kunz, A. (2019) Co-Digestion of Animal Manure and Carcasses to Increase Biogas Generation. Improving Biogas Production, 9, 99-116. https://doi.org/10.1007/978-3-030-10516-7_5

[26] Rapport, J.L., Zhang, R., Jenkins, B.M., Hartsough, B.R. and Tomich, T.P. (2011) Modeling the Performance of the Anaerobic Phased Solids Digester System for Biogas Energy Production. Biomass Bioenergy, 35, 1263-1272. https://doi.org/10.1016/j.biombioe.2010.12.021

[27] Locher, C., Meyer, C. and Steinmetz, H. (2012) Operating Experiences with a Molten Carbonate Fuel Cell at Stuttgart-Möhringen Wastewater Treatment Plant. Water Science and Technology, 65, 789-794. https://doi.org/10.2166/wst.2012.463

[28] Intanoo, P., Chaimongkol, P. and Chavadej, S. (2016) Hydrogen and Methane Production from Cassava Wastewater Using Two-Stage Upflow Anaerobic Sludge Blanket Reactors (UASB) with an Emphasis on Maximum Hydrogen Production. International Journal Hydrogen Energy, 41, 6107-6114.

https://doi.org/10.1016/j.ijhydene.2015.10.125

[29] Dahiya, S., Kumar, A.N., Shanthi Sravan, J., Chatterjee, S., Sarkar, O. and Mohan, S.V. (2018) Food Waste Biorefinery: Sustainable Strategy for Circular Bioeconomy. Bioresource Technology, 248, 2-12. https://doi.org/10.1016/j.biortech.2017.07.176

[30] Banks, C.J., Salter, A.M., Heaven, S. and Riley, K. (2011) Energetic and Environmental Benefits of Co-Digestion of Food Waste and Cattle Slurry: A Preliminary Assessment. Resources, Conservation and Recycling, 56, 71-79. 
https://doi.org/10.1016/j.resconrec.2011.09.006

[31] He, C., Giannis, A. and Wang, J. (2013) Conversion of Sewage Sludge to Clean Solid Fuel Using Hydrothermal Carbonization: Hydrochar Fuel Characteristics and Combustion Behavior. Applied Energy, 111, 257-266.

https://doi.org/10.1016/j.apenergy.2013.04.084 